Kamil Śmiechowski

(Uniwersytet Łódzki, Wydział Historyczno-Filozoficzny)

\title{
W KWESTII PEWNEGO NIEPOROZUMIENIA
}

$\mathrm{J}$ ednym z najważniejszych elementów poważnej pracy naukowej jest gotowość na poddanie jej efektów oglądowi czytelników, zaś procedura recenzencka, słusznie, urasta do miana jednej z najważniejszych form kontroli jakości i oceny, wyróżniających aktywność naukową z całej masy dostępnych współcześnie form i środków przekazu. Z tego też powodu radość i uznanie budzić musi fakt, iż wydana niedawno nakładem Wydawnictwa Uniwersytetu Łódzkiego książka Robotnicy Łodzi drugiej połowy XIX wieku. Nowe kierunki badawcze ${ }^{1}$, autorstwa Marty Sikorskiej-Kowalskiej, Kenshi Fukumoto oraz niżej podpisanego znalazła recenzenta w osobie prof. Krzysztofa P. Woźniaka, historyka i etnologa, niewątpliwie niezwykle kompetentnego i cenionego autora prac z zakresu historii Łodzi, autora m.in. niedawno wydanej, nagradzanej pracy o Rajmundzie Rembielińskim ${ }^{2}$. Mimo jednak całej sympatii dla osoby i dorobku Recenzenta, którego - co chciałbym podkreślić na wstępie - darzę szacunkiem, z żalem muszę napisać, że przygotowany przez Niego artykuł recenzyjny Łódzcy robotnicy z trzech perspektyw oglądani ${ }^{3}$ sprawia wrażenie bycia pokłosiem sporego nieporozumienia. Zaszczycony jednak faktem złożenia do druku tejże recenzji, pozwolę sobie wyprostować kilka zawartych w niej zarzutów.

Lista krytycznych uwag, jaką wystosował K.P. Woźniak pod adresem naszej książki jest obszerna na tyle, że polemika z nimi wykracza dalece poza kompetencje pojedynczego autora, dlatego oddając pole w przypadku części autorstwa M. Sikorskiej-Kowalskiej i K. Fukumoto samym zainteresowanym, skupię się jedynie na zarzutach, które stawia Recenzent rozdziałowi mojego autorstwa. Odniosę się również do niektórych z ogólnych uwag sformułowanych pod naszym adresem przez Recenzenta, w sporej mierze - jak sądzę - pozwalają one na zrozumienie narosłych nieporozumień.

${ }^{1}$ K. Śmiechowski, M. Sikorska-Kowalska, K. Fukumoto, Robotnicy Łodzi drugiej połowy XIX wieku. Nowe kierunki badawcze, Łódź 2016.

${ }^{2}$ K.P. Woźniak, Rajmund Rembieliński, wizjoner i menedżer Łodzi przemystowej. Raporty z lat 1824-1830, Łódź 2016.

3 „Studia z Historii Społeczno-Gospodarczej XIX i XX wieku” 2017, t. 17, s. 179-198. 
Jak pisze Recenzent, moje twierdzenie, że na przełomie XIX i XX w. robotnicy stanowili 70\% ogółu mieszkańców Łodzi „budzi ogromne zdziwienie”. Odwołując się do jednego z przekazów prasowych z epoki, w której liczba łódzkich robotników została oszacowana na 40 tys. Recenzent przekonuje, że dopiero w 1914 r. liczba ta urosła do poziomu 100 tys. osób, zaś w nawiązaniu do prac Juliana Janczaka, Władysława Lecha Karwackiego i Pawła Samusia kategorycznie stwierdza, iż w latach 1885-1912 robotnicy stanowili ok. 20\% ogółu mieszkańców Łodzi. Jak pointuje, „między niespełna 30\% a 70\% różnica jest niebagatelna”, a nawet ,zgoła fundamentalna”.

Nieporozumienie, a z takim mamy tu do czynienia wynika jak sądzę z faktu, iż Recenzent zdaje się traktować jako robotników wyłącznie osoby zatrudnione w fabrykach, podczas, gdy oczywistym jest, iż dla mnie, a także i innych Autorów recenzowanej książki punktem odniesienia jest społeczność robotnicza, nie zaś pracownicy fabryk sensu stricto. Jak piszę we Wstępie, celem mojego artykułu było „pytanie o miejsce społeczności robotniczej, stanowiącej zdecydowaną większość mieszkańców (około 70\%), w życiu przemysłowego miasta"”. W innym miejscu wyraźnie, jak sądzę, deklaruję o kogo chodzi w moim tekście pisząc

dane te są o tyle istotne, że choć mówią o społeczności robotniczej w szerszej skali to charakteryzują procesy, które zachodziły również i na obszarze Łodzi. To właśnie łódzkie robotnice, robotnicy i ich dzieci przesądzali o młodości demograficznej Łodzi ${ }^{5}$.

Pisząc zatem, iż robotnicy rozumiani jako warstwa ludności stanowi zdecydowaną większość mieszkańców miasta mam na myśli oczywiście całokształt tej społeczności, zatem również i dzieci robotnic, i robotników przemysłowej Łodzi, a zatem osoby nieaktywne zawodowo, a także osoby w wieku poprodukcyjnym. Oczywistym jest, iż w moim rozumieniu społeczność robotnicza to coś więcej aniżeli społeczność pracowników fabryk!

Warto zresztą przy tej okazji zobaczyć, jak termin „społeczność” (ang. community) jest rozumiany przez współczesną socjologię. Podkreśla się, że pojęcie to bywa definiowane na dwa różne sposoby. Niekiedy odnosi się je do

istoty tożsamości zbiorowej, trwałych więzi emocjonalnych oraz harmonii społecznej pojawiającej się między jednostkami i opartej na osobistej znajomości i bezpośrednich kontaktach.

W tym rozumieniu społeczność niekoniecznie musi mieć wymiar przestrzenny, zaś tym, co ją konstruuje, są wspólnie wyznawane wartości, tożsamość zbiorowa czy po prostu obiektywne zależności między członkami grupy. Inni rozumieją jednak społeczność w kontekście miejsca jej egzystencji. Zorganizowana wokół

${ }^{4}$ Wstęp, [w:] Robotnicy Lodzi..., s. 8.

${ }^{5} \mathrm{~K}$. Śmiechowski, Łódź przełomu wieków XIX i XX - miasto robotników?, [w:] Robotnicy Łodzi..., s. 18. 
pewnego terytorium, społeczność może mieć wymiar lokalny bądź terytorialny, np. narodowy ${ }^{6}$. W przypadku łódzkich robotników mamy do czynienia ze współwystępowaniem obu tych wymiarów, grupę tę wyróżniały od innych zarówno czynniki obiektywne w postaci więzów rodzinnych, jak i pewne wspólnie wyznawane wartości, przejawiające się w postaci określonego stylu życia, odmiennego chociażby od bliższych drobnomieszczaństwu robotników warszawskich, a określanego jako „kultura robotnicza”, jak również wymiar czysto lokalny, polegający na zamieszkiwaniu w Łodzi i na jej przedmieściach?

Takie ujęcie zagadnienia wydaje się zresztą jedynym sensownym, zredukowanie sfery, jaką stanowił proletariat Łodzi do pracowników fabryk prowadziłoby bowiem do ograniczenia rozważań o roli robotników w życiu miasta do stosunków pracy, podczas gdy w literaturze przedmiotu nie budzi zastrzeżeń fakt, iż industrializacja była procesem dotykającym wszystkich dziedzin życia i funkcjonowania miast, zaś pojawienie się klasy robotniczej jako nowego aktora, rzutowało na całokształt stosunków społecznych. Jak pisał Eric Hobsbawm:

uprzemysłowienie, z jego charakterystyczną strukturą i otoczeniem, a także urbanizację - życie w rozrastających się miastach - z pewnością uznać trzeba za najbardziej spektakularne przejawy nowego świata; nowego, ponieważ nawet ciągłość pewnych lokalnych zawodów czy trwałość takiego lub innego miasteczka zawierały w sobie wprawdzie nieco utajone, ale dalekosiężne zmiany ${ }^{8}$.

Wracając jednak do materialnego aspektu zarzutu stawianego mi przez Recenzenta, tj. przeszacowania rozmiarów łódzkiej społeczności robotniczej warto pokreślić, iż przede wszystkim nie jest zgodne z rzeczywistością przypisywanie mi autorstwa stwierdzenia, jakoby stanowiła ona zdecydowaną większość mieszkańców miasta. Tezę tę formułuje wprost w swojej klasycznej już książce Dzieje Łodzi przemystowej. Zarys historii ${ }^{9}$ profesor Wiesław Puś, co w swoim rozdziale opatrzyłem w powszechnie akceptowalny w świecie nauki sposób, a mianowicie przypisem. Fakt, iż - co jak sądzę musiało umknąć Recenzentowi - teza ta jest $\mathrm{w}$ istocie tezą prof. Pusia, nie zwalnia mnie jednakowoż przed podjęciem się jej obrony. Nie jest bowiem tak, iż przywołując ją w swoim tekście, uczyniłem to w sposób bezrefleksyjny.

W. Puś w swojej książce pisze:

niezwykle trudno jest zobrazować strukturę klasowo-warstwową mieszkańców Łodzi, ponieważ ówczesne źródła podawały jedynie podział ludności wg zajęć. [...] Na podstawie

${ }^{6}$ Zob. P. Starosta, Społeczność lokalna, [w:] Encyklopedia socjologii, t. 4, Warszawa 2002, s. $97-108$.

${ }^{7}$ Zob. m.in. A. Żarnowska, Klasa robotnicza Królestwa Polskiego 1870-1914, Warszawa 1974, s. 187-193, 217-222.

${ }^{8}$ E. Hobsbawm, Wiek kapitatu 1848-1875, Warszawa 2014, s. 300.

9 W. Puś, Dzieje Łodzi przemysłowej (zarys historii), Łódź 1987. 
spisu z 1897 r. oraz danych pośrednich możemy w przybliżeniu określić, że w tym czasie w strukturze społecznej łodzian 72\% stanowili robotnicy, $20 \%$ drobnomieszczaństwo (rzemiosło, drobny handel), $5 \%$ inteligencja oraz $3 \%$ burżuazja $^{10}$.

Lektura wywodu W. Pusia jednoznacznie pokazuje, że Autor ma tu na myśli podział rozmaitych grup zamieszkujących ,polski Manchester” przełomu wieków na klasy społeczne, zaś 72\% stanowi dlań szacunek wielkości łódzkiego proletariatu, nie zaś liczbę zatrudnionych w fabrykach, do której odnosi się K. Woźniak w recenzji naszej książki.

Ostatecznym rozstrzygnięciem może być jednak odwołanie do prac, które zdaniem Recenzenta wskazują na rzeczywistą liczebność robotników w XIX-wiecznej Łodzi. Jak pisze K.P. Woźniak:

wyniki badań źródłowych Juliana Janczaka, Władysława Lecha Karwackiego i Pawła Samusia nie pozostawiają wątpliwości, że w latach 1885-1912 robotnicy stanowili ok. 20\% ogółu mieszkańców Łodzi, przy czym w 1893 r. odsetek ten był maksymalnie wysoki, osiągając wartość $26,7 \%$.

Wszystkie te dane są słuszne, pod warunkiem, że mówimy jedynie o zatrudnionych w fabrykach, a nie o społeczności. Co więcej, dokładna analiza wskazanych przez Recenzenta prac ${ }^{11}$ wskazuje, że ich autorzy nie mieli problemu z przyznaniem, że społeczność robotnicza stanowiła większość mieszkańców przemysłowego miasta.

Na początek warto sięgnąć do kanonicznej dla badaczy ówczesnej Łodzi książki Juliana Janczaka Ludność Łodzi przemystowej 1820-1914. Omawiając wyniki spisu powszechnego z $1897 \mathrm{r}$. autor ów pisał: „spośród prawie 127 tysięcy osób mających zajęcie ponad $58 \%$ pracowało w przemyśle i rzemiośle, $22 \% \mathrm{w}$ dziale służba domowa, wyrobnicy itp."12. Zaliczanie do łódzkiego proletariatu osób z tej grupy jest niewątpliwie zasadne, gdyż osoby je wykonujące wywodziły się z tych samych źródeł rekrutacji, co robotnicy, a ponadto byli z nimi związani więzami rodzinnymi (np. dziewczęta z rodzin robotniczych zatrudniające się w charakterze służby). Tabela umieszczona na stronach 158-159 pracy J. Janczaka uwzględnia ponadto osoby bierne zawodowo. Według umieszczonych w niej danych przemysł i rzemiosło miały odpowiadać za utrzymanie ogółem 56,1\%, zaś do działu 6 obejmującego służbę domową, wyrobników itp. przynależało 17,4\% ludności miasta $^{13}$. Uwzględniając nawet niedostatki rosyjskiej statystyki, która liczyła łącz-

10 Tamże, s. 70-71.

${ }^{11}$ P. Samuś, $W$ walce o wyzwolenie narodowe i społeczne (1893-1918), [w:] W dymach czarnych budzi się Łódź. Z dziejów tódzkiego ruchu robotniczego 1882-1948, Łódź 1985, s. 76; W.L. Karwacki, Sytuacja społeczno-polityczna łódzkich włókniarzy w latach 1908-1914, [w:] Włókniarze tódzcy. Monografia, pod red. E. Rosseta, Łódź 1966, s. 76.

12 J. Janczak, Ludność Łodzi przemystowej 1820-1914, Łódź 1982, s. 160.

13 Tamże, s. 158. 
nie właścicieli fabryk i ich podwładnych, nie sposób upierać się przy twierdzeniu jakoby robotnicy wraz z rodzinami nie stanowili zdecydowanej większości mieszkańców miasta. J. Janczak pokusił się zresztą o oszacowanie liczby osób utrzymujących się w Łodzi z przemysłu i rzemiosła w przededniu I wojny światowej. Jak stwierdził, szacuje się

ogólne zatrudnienie w przemyśle i rzemiośle łódzkim na poziomie ok. 135 tysięcy osób. Po zastosowaniu do tej liczby wskaźnika aktywności zawodowej w tym dziale gospodarki z końca XIX w. - ok. $60 \%$ - okaże się, że przemysł i rzemiosło dostarczały wówczas środków utrzymania dla ok. 225 tys. mieszkańców Łodzi ${ }^{14}$.

Również i profesor Paweł Samuś jest daleki od redukowania liczebności społeczności robotniczej w Łodzi do zatrudnionych w fabrykach. Jak pisze w swojej pracy, zgodnie z sugestią Recenzenta, robotnicy stanowili w roku 1893 26,7\% mieszkańców miasta, co i tak czyniło z Łodzi fenomen społeczny na tle innych ośrodków w Polsce. Szkoda jednak, że Recenzent nie skupił wystarczająco wiele uwagi na kontekście tej wypowiedzi, a nie pozostawia on złudzeń co do wielkości społeczności robotniczej w strukturze ludności miasta. Jak przekonuje bowiem P. Samuś:

Należy także zaznaczyć, że istniała dość liczna grupa robotników zatrudnionych w zakładach pozostających poza oficjalną statystyką Inspekcji Fabrycznej. Z przemysłem włókienniczym związani byli tkacze ręczni. Uzależnieni od nakładcy, zajmowali pod względem społeczno-ekonomicznym pozycję między drobnymi wytwórcami i proletariatem; w częstych okresach kryzysów stawali się robotnikami najemnymi, poszukującymi pracy w przemyśle. Na początku XX w., wg szacunków badaczy, w Łodzi pracowało ok. 7 tys. tkaczy ręcznych.

Prawdopodobnie trzykrotnie więcej pracowników zatrudniało bardzo dobrze rozwinięte rzemiosło łódzkie, a w szczególności krawiectwo i szewstwo. Ogółem proletariat przemysłowy i rzemieślniczy wraz z rodzinami stanowił większość mieszkańców miasta $(\text { podkr. - K.Ś. })^{15}$.

Jak wynika z powyższych odniesień, niestety, zapewne na skutek nieporozumienia, Recenzentowi umknął fakt, że również i zdaniem autorów dogłębnie badających stosunki zawodowe w Łodzi liczebność społeczności robotniczej Łodzi była znacznie bliższa 70\% niż 30\% ludności, a to właśnie wielkość społeczności, a nie bezwzględna liczba zatrudnionych w fabrykach decydowały o proletariackim charakterze miasta.

Nieporozumienie to prowadzi zresztą do dość zabawnych reperkusji, gdy Recenzent wyrażając zdziwienie z powodu mojej deklaracji o stosowaniu wymiennie terminów klasy i warstwy społecznej w tekście stwierdza, iż

14 Tamże, s. 169.

${ }^{15}$ P. Samuś, $W$ walce..., s. 76. 
do analizy problemów społeczeństwa Łodzi znakomicie przystaje weberowska typologia klasy i warstwy społecznej, i rolą historyka jest użycie jasno zdefiniowanego instrumentarium pojęciowego, zwłaszcza w problematyce, którą zaczęto badać już przed wiekiem i rozróżnienie między klasą a warstwą nie budzi dziś wątpliwości.

Sęk w tym, że poczyniona przeze mnie uwaga jest jedynie wyjaśnieniem pod adresem czytelników, mającym na celu uniknięcie chaosu terminologicznego, zaopatrzonym uwagą o języku źródeł, nie zaś żadną odezwą do porzucenia posługiwania się terminologią odnoszącą się do stratyfikacji społecznej w naukach historycznych. Co więcej, K.P. Woźniak ma słuszność, gdy pisze, że „ukształtowany w minionych dziesięcioleciach obraz wielkomiejskiego środowiska robotniczego, przedstawia je schematycznie, jako homogeniczny monolit”, zaś badania nad strukturą warstwową łódzkiego proletariatu stanowiłyby istotne novum. Niestety jednak wykazuje się niekonsekwencją nie zauważając, iż niezależnie od tego, czy przyjąć by weberowską czy marksowską definicję klasy społecznej, społeczność robotników łódzkich i tak należałoby uznać za grupę stanowiącą zdecydowaną większość, a nie jedynie - jak chce - około $30 \%$ ludności miasta.

Warto zresztą w tym miejscu zauważyć, że zarówno definicja Webera, jak i definicja Marksa, odgrywają coraz mniejszą rolę we współczesnych naukach społecznych, które bynajmniej nie traktują pojęcia klasy społecznej jako archaizmu. W odróżnieniu od państw „realnego socjalizmu”, w których celem analiz klasowych było przede wszystkim dzielenie społeczeństwa na poszczególne grupy i przeciwstawianie ich sobie (można wymienić całą litanię autorów, którzy chcąc być ślepo wiernymi tej wykładni nazywali np. prasę pozytywistów warszawskich mianem „burżuazyjnej” podczas, gdy w istocie była ona co najwyżej „mieszczańską”) w imię zgodności z pewnym odgórnie narzuconym gorsetem ideologicznym, na Zachodzie częściej skupiano się raczej na objaśnianiu samej logiki podziałów klasowych. Jak pisał więc badacz angielskiego proletariatu E.P. Thompson, mówiąc o klasie społecznej należałoby raczej mówić o relacji między ludźmi, nie zaś o jakiejś strukturze funkcjonującej w społeczeństwie ${ }^{16}$. W opinii tego historyka przynależność do danej klasy objawia się zatem w tym, w jaki sposób obiektywnie istniejące rozbieżne interesy ekonomiczne warunkują kształt relacji między poszczególnymi ludźmi, a co za tym idzie - wytwarzają poczucie przynależności odpowiednio do burżuazji czy proletariatu. Tak rozumiane poczucie przynależności jest zaś wcześniejsze niż jego określenie - robotnik najpierw odczuwa rozbieżność interesów między nim a majstrem, a dopiero później (jeśli w ogóle) racjonalizuje ją jako konflikt klasowy. W tym właśnie kontekście nowe badania nad łódzkimi robotnikami w XIX i XX w., na przykład analiza statusu majstrów jako grupy lokującej się pomiędzy pracownikami a ich pracodawcami, byłyby istotnie bardzo pożądane. I choć K.P. Woźniak upomina

${ }^{16}$ E. P. Thompson, The Making Of The English Working Class, London 1963, s. 8. 
się słusznie o rozważania nad strukturą warstwową łódzkiego proletariatu trzeba jednak zrazu podkreślić, że nie da się ich jednak prowadzić bez sięgnięcia po nowsze narzędzia teoretyczne, co zapewne mogłoby nie znaleźć uznania w oczach Recenzenta.

Trudno bowiem oprzeć się wrażeniu, że niechęć przed stosowaniem różnego rodzaju ,nowinek metodologicznych” w historiografii nie pozwala K.P. Woźniakowi spojrzeć na naszą książkę w obiektywny sposób. Chwilami aż nadto ujawnia się konserwatywna postawa Recenzenta wobec rozmaitych typów źródeł, co prowadzi do wysuwania pod adresem współautorów oraz moim zarzutów nie tylko niesprawiedliwych, ale bardzo nieproporcjonalnych w stosunku do rzeczywistych mankamentów naszej książki, których oczywiście jej nie brakuje. Recenzent pisze m.in. tak ostre słowa:

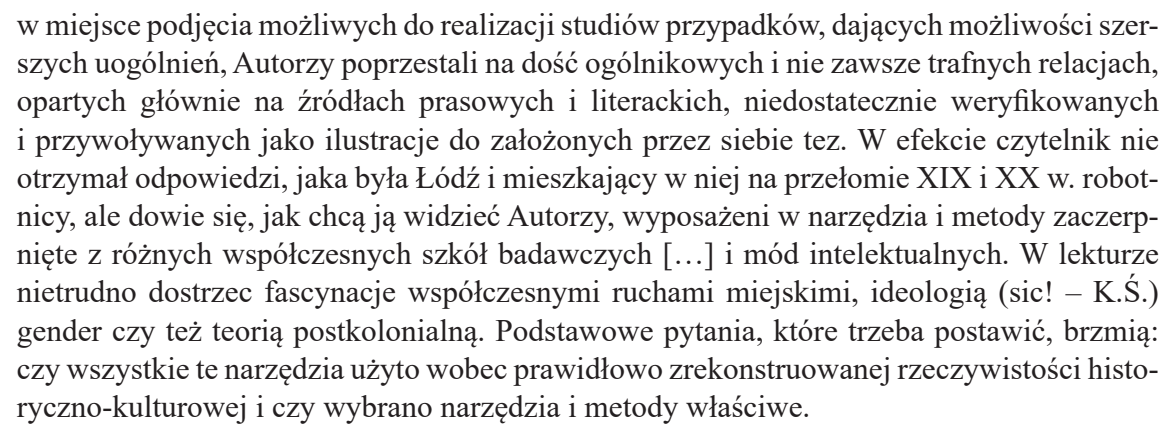

Trudno o rzeczową polemikę, gdy ma się do czynienia z tak silnie nacechowanymi emocjonalnie osądami. Zarzucanie mi i pozostałym Autorom pisania pod z góry założone tezy, na dodatek w oparciu o niedostatecznie zweryfikowane źródła, nie wydaje się przekonywające w sytuacji, gdy zarzutom tym towarzyszą wątpliwej jakości odwołania do stanów emocjonalnych poszczególnych autorów, nazywane przez Recenzenta mianem „fascynacji” czy oceniające, lekceważące określenia przyjętych przez nich perspektyw, a za takie należy uznać nazywanie badań nad zjawiskiem płci kulturowej mianem ,ideologii”. Co ważniejsze jednak, odpowiedź na zadane przez Recenzenta pytanie o zasadność użytych przez nas narzędzi nie jest aż tak negatywna, jak wyobraża to sobie Recenzent.

Dzieje się tak choćby w przypadku moich uwag o przestrzeni miejskiej Łodzi. Zdaniem K.P. Woźniaka nie jest prawdziwą osadzona przecież ściśle w dorobku badaczy takich jak Marek Koter czy Krzysztof Stefański ${ }^{17}$, a powtórzona przeze mnie teza o bezplanowym charakterze rozwoju urbanistycznego Łodzi, przekładającym się ,na silny niedostatek typowych przestrzeni publicznych, w postaci

${ }^{17}$ O bezplanowym rozwoju Łodzi po 1850 r. pisali m.in.: M. Koter, Geneza uktadu przestrzennego Łodzi przemystowej, Warszawa 1969; K. Stefański, Jak zbudowano przemystowa Łódź. Architektura i urbanistyka miasta w latach 1821-1914, Łódź 2001. 
reprezentacyjnych placów czy parków". By to udowodnić, Recenzent pisze, iż „przestrzenią miejską, przestrzenią publiczną były także tereny zielone położone w granicach miasta i na jego obrzeżach". Pomijając oczywisty absurd rozumowania K.P. Woźniaka, jak rozumiem zdającego się zaliczać las do... przestrzeni miejskich, aż chce się zadać Recenzentowi pytanie, czy mieszkańcy Łodzi rzeczywiście spotykaliby się w lasach i przy dawnych stawach wiejskich licznie występujących w sąsiedztwie szybko rozwijającego się miasta, gdyby oferowało im ono w wystarczającej ilości jako miejsce rozrywek i zabaw urządzoną przestrzeń miejską sensu stricto, czyli parki oraz place publiczne? Wiem oczywiście, że na początku XX w. dokonał się w tym obszarze znaczący postęp dzięki wytyczeniu dzisiejszych parków Poniatowskiego i Staszica, w żadnym razie nie podważa to jednak tezy o niedostatku terenów zielonych w Łodzi na przełomie stuleci. Nie jest też najlepszą wizytówką miasta fakt, iż - co przyznaje sam Recenzent - ,wszystkie place pełniły rolę targowisk; innych placów nie było”. K.P. Woźniak pisząc tego typu uwagi być może nieświadomie nie tylko nie rozprawia się z moimi tezami, ale jeszcze je dodatkowo wzmacnia.

Podobnie rzecz się ma z uwagą dotyczącą braków instytucjonalnych przemysłowej Łodzi. K.P. Woźniak, chcąc podważyć moją tezę o rażących brakach w tym zakresie, wylicza stowarzyszenia religijne i fachowe, szkoły, szpitale, tramwaje i inne miejskie urządzenia miejskie, które powstały przed rokiem 1905. Szkoda, że nie dostrzega, że wymienione przez Niego urządzenia i instytucje, których wkładu w rozwój społeczno-kulturalny, gospodarkę i higienę Łodzi nikt przecież nie śmie podważać, miały charakter prywatny lub były efektem zorganizowanej filantropii, czyli oddolnych działań społecznych. A zatem powstawały one jako substytut instytucji, za powołaniem których powinny odpowiadać władze, podczas gdy „urządzenia dobroczynne” z natury rzeczy winny raczej służyć wspieraniu władz w ich działaniach m.in. poprzez powoływanie instytucji rozszerzających, a nie zastępujących działalność tych miejskich czy państwowych. Znów mamy tu zatem do czynienia z zabiegiem, który choć ma obalić powszechną zarówno w publicystyce, jak i literaturze fachowej tego okresu opinię o skrajnym zaniedbaniu Łodzi w zakresie jej funkcji wielkomiejskich, jedynie potwierdza jej słuszność.

Warto zresztą w tym miejscu wskazać na głębszą refleksję dotyczącą szkód, jakie w obiektywnej ocenie przeszłości naszego miasta dokonały zmiany, które nastąpiły w polskiej historiografii po 1989 r. Zrozumiałe przełamywanie nacechowanej ideologicznie narracji dominującej w Polsce Ludowej szło bowiem $\mathrm{w}$ parze $\mathrm{z}$ zaniedbywaniem prac $\mathrm{w}$ obszarach, które wcześniej uprawiane były w sposób nieobiektywny, zaś w nowych realiach zamiast zapomnienia, tym bardziej powinny wymagać nowych interpretacji. W rezultacie, jak bardzo celnie napisał inny recenzent naszej książki: 
antyrobotnicze skrzywienie rzutowane z przeszłości sprawia, że wszyscy znamy dobrze atrakcyjny awers dawnej Łodzi, mniej chętnie rozmawiamy o rewersie prosperity doby «carskiego kapitalizmu». Podziwiając fabryki i pałace, nie należy zapominać o wszechobecnych wtedy suterenach i sutenerach. Doceniając rozwój i postęp, trzeba podkreślić, że były też głód i deprawacja. Choć rosły prywatne zyski, zbywało na wszystkim, co wspólne: szkołach, szpitalach, nawet kanalizacji ${ }^{18}$.

Swój wywód na temat osiągnięć infrastrukturalnych przemysłowej Łodzi konkluduje K.P. Woźniak pisząc, iż

wśród przyczyn zaniedbań łódzkich widzieć trzeba zarówno brak osobowości na miarę Starynkiewicza wśród włodarzy miasta, jak i mimo wszystko relatywnie małe zaangażowanie miejscowej, wielonarodowej burżuazji w sprawy publiczne,

czym sam poniekąd przyznaje rację wysuniętej przez Agatę Zysiak i Wiktora Marca, ale znanej w literaturze dotyczącej Rosji carskiej od lat tezie o systemowej niechęci tegoż imperium do podejmowania systemowych interwencji $\mathrm{w}$ sferze publicznej przy jednoczesnym kurczowym trzymaniu się leseferyzmu gospodarczego. Jak przekonuje niemiecki historyk Malte Rolf w swojej znakomitej pracy o rosyjskich rządach imperialnych w Królestwie:

Niemal całkowity brak państwowych inwestycji w wymagającą pilnych działań bazę mieszkaniową - w szerokiej perspektywie - nie był niczym wyjątkowym, co negatywnie wyróżniałoby nadwiślańską metropolię. Podobnie było w wielkich miastach we wnętrzu Rosji, a także w miastach monarchii habsburskiej. Dominujący pogląd był wciąż bowiem taki, że sterowanie i ingerowanie w rynek najmu lokali nie należały do zadań państwa ani administracji miejskiej. W wielu częściach aparatu administracyjnego wciąż panowała tradycyjna koncepcja ,administracji porządkowej”, zorientowanej przede wszystkim na „Zapewnienie spokoju i ładu w sferze publicznej”"19.

Jednak z perspektywy społeczeństwa polskiego, które chciało widzieć Królestwo jako część kulturowego i cywilizacyjnego Zachodu, a nie Wschodu naturalnym było poczucie, że gdy władzom miejskim zbywa na szkoły elementarne czy wodociągi, posiadanie pierwszych w Królestwie tramwajów elektrycznych staje się mało satysfakcjonujące...

Przywoływanie Sokratesa Starynkiewicza jako przykładu dobrego gospodarza, którego zabrakło przemysłowej Łodzi, również jest chybione, bowiem po pierwsze możliwości działania prezydentów Warszawy, trzeciego największego miasta carskiej Rosji, były w tym czasie mimo wszystko nieco większe niż w innych

18 M. Giełzak, „Kwestia robotnicza” wciąż aktualna, https://wydawnictwo.uni.lodz.pl/2017/ 05/12/kwestia-robotnicza-wciaz-aktualna/, [21.05.2017].

${ }_{19}$ M. Rolf, Rządy imperialne w Kraju Nadwiślańskim. Królestwo Polskie i cesarstwo rosyjskie (1864-1915), Warszawa 2016, s. 198. 
miastach Królestwa, po drugie zaś, sam fakt, że upór i determinacja jednostki decydowały o zaopatrzeniu danego miasta w podstawowe osiągnięcia cywilizacyjne znów świadczy jedynie o systemowym podłożu niedorozwoju miast Królestwa Polskiego w owym czasie, wynikającym z polityki prowadzonej w Petersburgu. Nawiasem mówiąc dziwi, że Recenzent omija zupełnie postać wieloletniego prezydenta miasta Łodzi Władysława Pieńkowskiego, a jest to przecież postać wybitnie niejednoznaczna i wymagająca pogłębionych badańn ${ }^{20}$.

Dziwi też sformułowana przez K.P. Woźniaka negacja znaczenia rewolucji 1905 roku jako punktu zwrotnego w dziejach miast i ich sfery instytucjonalnej. Wysyp wszelkiego rodzaju stowarzyszeń, szkół czy nowych tytułów prasowych, jaki dokonał się w tych „czasach wolnościowych”, nie powinien wszak budzić żadnych zastrzeżeń ${ }^{21}$. Również i możliwości otwartej krytyki władz miejskich, formułowania nowych, całościowych programów rozwoju ośrodków miejskich w związku z planowanym samorządem oraz różnicowania się poglądów na temat poszczególnych aspektów funkcjonowania miast po roku 1905 stały się, nieodwracalnie zresztą, wielokrotnie większe niż wcześniej ${ }^{22}$.

Lata 1905-1907 i porewolucyjne w Królestwie Polskim były okresem przełomu świadomościowego, podnoszącego aspiracje elit i przesuwającego punkt ciężkości w myśleniu zarówno o całym kraju, jak i o jego potrzebach, również w zakresie gospodarki miejskiej, z poziomu marzeń na pole możliwości. Związek przyczynowo-skutkowy między odezwą łódzkiej inteligencji w sprawie walki z analfabetyzmem z grudnia 1905 r., a działalnością pierwszej demokratycznie wybranej rady miasta, która zdołała jako pierwsza w Odrodzonej Polsce wprowadzić w Łodzi powszechne nauczanie, jest wszak aż nadto wyraźny i nie widać powodów do jego kwestionowania.

Recenzent doszukuje się w książce „mitu ulicy Piotrkowskiej”, dogmatycznie odrzucając liczne w publicystyce przełomu wieków relacje o olbrzymich rzeszach robotników, którzy szli pieszo do i z pracy zapełniając Piotrkowską i inne ulice miasta. Zdaniem K.P. Woźniaka, opowieści te są zupełnie nieprawdziwe, gdyż w Łodzi przełomu wieków

racjonalne było też zamieszkanie możliwie blisko miejsca pracy. Wymuszał to bilans czasu przeznaczanego na pracę zawodową (do 1906 r. 11,5 godziny) i na wypoczynek. Do domów wracano najkrótszą drogą.

${ }^{20}$ Zob.: K. Śmiechowski, Między rzeczywistościa biurokratyzmu a utopia samorządu. Krytyka prasowa miejskiego aparatu urzędniczego w rewolucji 1905 roku na przykładzie Łodzi, [w:] Między irredenta a kolaboracja. Ugoda, lojalizm i legalizm. „Dusza urzędnika” - zewnętrzna akceptacja i wewnętrzna niezgoda?, pod red. N. Kasparka i M. Klemperta, Olsztyn 2015, s. 105-125.

${ }^{21}$ Zob. W. L. Karwacki, Łódź w latach rewolucji 1905-1907, Łódź 1975, s. 242-258, 285-338.

22 Zob.: K. Śmiechowski, Ku miastu politycznemu: przemiany miejskiego dyskursu prasowego w dobie rewolucji 1905 roku, [w:] Polityka i politycy w prasie XX i XXI wieku, red. M. Dajnowicz, Białystok 2016, s. 128-138. 
Znów jest to oczywiście prawda, jednakowoż zdumiewa, że Recenzent doskonale przecież znający topografię miasta i rozkład przestrzenny rozsianych na jego terenie zakładów przemysłowych, sąsiadujących z kamienicami i innymi obiektami miejskimi nie dostrzega, że dla sporej części robotnic i robotników to właśnie Piotrkowska stanowiła „,najkrótszą drogę”. Co więcej, siatka uliczna przemysłowej Łodzi pozostawała tak ubogą, iż dawny trakt piotrkowski stanowił w zasadzie jedyną ulicę sensownie łączącą północne i południowe dzielnice Łodzi. Którędy mieli zatem, zdaniem Recenzenta, iść do pracy mieszkańcy choćby olbrzymich łódzkich przedmieść, Bałut i Chojen, skoro innej drogi do miasta po prostu wówczas nie było? Recenzent zapomniał chyba, że Piotrkowska stanowiła drogę krajową jeszcze w drugiej połowie XX w. i to bynajmniej nie z powodu nadmiaru alternatywnych połączeń drogowych w centrum Łodzi... Wreszcie, aż nie chce się wierzyć, by Recenzentowi uszło z pamięci, że i przy Piotrkowskiej mieściło się też kilka wielkich fabryk - Geyera, Heinzla, Silbersteina, Ramischa i Johna, nie licząc już tych „ukrytych" w podwórkach, do których robotnicy musieli chyba się jakoś dzień w dzień dostawać... Szczególna rola Piotrkowskiej, jako jedynej wielkomiejskiej ulicy tego przemysłowego miasta, skupiającej w sobie funkcje, które w pozostałych ośrodkach były rozrzucone po całym obszarze śródmiejskim, nie zasługuje na kontestację.

K.P. Woźniak słusznie podkreśla, iż Łódź przełomu XIX i XX w. stanowiła organizm silnie zdezintegrowany, zaś kontakty między mieszkańcami poszczególnych dzielnic były ograniczone. Nie jest to rzecz jasna teza odkrywcza, pojawia się zresztą również i w moim tekście, a także cytowanym przeze mnie artykule M. Iwańskiej ${ }^{23}$. Przywoływanie jako kontrargumentu książki Pauliny Tobiasz-Lis ${ }^{24}$ jest przeciwskuteczne, albowiem praca ta odnosi się do współczesnej przestrzeni miejskiej, która na przestrzeni ostatnich 100 lat uległa jednak znaczącej reorganizacji w kierunku centrum wielkiego miasta, zaś odniesienie do zawartych w książce P. Tobiasz-Lis ogólnych uwag na temat percepcji przestrzeni miejskiej, skądinąd bardzo ciekawych, nie zmieniłoby ani trochę ogólnej oceny niskiej jakości przestrzeni Łodzi w okresie jej wielkoprzemysłowego rozkwitu. Trzeba zresztą $\mathrm{w}$ tym miejscu podkreślić, iż zastosowana przez P. Tobiasz-Lis metoda, czyli ankiety z mieszkańcami siłą rzeczy jest nieosiągalna dla historyka pragnącego pisać o łódzkiej przestrzeni miejskiej, zaś z dostępnych źródeł prasa niewątpliwie jest najbardziej zbliżona do środków badawczych stosowanych przez geografię humanistyczną.

${ }^{23}$ M. Iwańska, Miasto i przestrzeń miejska w świadomości mieszkańców Łodzi przełomu XIX i XX wieku, [w:] Mity i stereotypy w dziejach Polski i Ukrainy w XIX i XX wieku, red. A. Czyżewski, Warszawa-Lódź 2012, s. 129-136.

${ }^{24}$ P. Tobiasz-Lis, Zmiany wyobrażeń mieszkańców Łodzi o przestrzeni miasta, Łódź 2013. 


\title{
Gdy piszę, że
}

nie ulega wątpliwości, że codzienne robotnicze przemarsze ulicami miasta miały pewien charakter demonstracyjny i podkreślały obecność większości mieszkańców miasta w jego przestrzeni

nie mam - jak widzi to K.P. Woźniak - na myśli demonstrowania przeciwko czemuś. Demonstracyjny charakter obecności robotników na Piotrkowskiej odnosi się w moim tekście do sfery symbolicznej, a nie politycznej. Fascynował i intrygował tak Reymonta, jak i jego naśladowców, którzy dzielili się później swoimi wrażeniami z czytelnikami. Nie ma powodu, by redukować ich nader liczne relacje o tłumach robotnic i robotników na ulicach miasta do sfery imaginarium. Jak się okazało w roku 1905, odczuwana przez mieszczaństwo i inteligencję „trwoga mas", by posłużyć się tą zgrabną figurą Ortegi y Gasseta, czyli silny strach przed ludem roboczym i jego aktywizacją polityczną nie był jedynie wytworem wyobraźni lecz realnym zagrożeniem, które - na dobre i na złe - wybuchło z siłą znacznie przekraczającą wyobraźnię współczesnych ${ }^{25}$.

Prowadzący niekiedy do wyolbrzymienia zarzutów dystans, jaki prezentuje K.P. Woźniak w stosunku do źródeł narracyjnych oraz współczesnych metod badawczych nie dziwi jeśli zważyć na silnie ugruntowane w klasycznej historiografii przekonanie o wyższości akt nad „subiektywnymi” źródłami wiedzy o przeszłości. Podobnie Recenzent pisze, iż

\begin{abstract}
wszyscy Autorzy dyskutowanej tu książki zauroczyli się łódzką publicystyką i, generalnie, przekazem literackim. Istotą publicystyki jest jej subiektywny charakter, tymczasem pod piórami Autorów dawne relacje otrzymały rangę przekazów obiektywnych. Jeszcze bardziej jest to widoczne przy odwołaniach do literatury beletrystycznej. Kreślone w niej obrazy „Z życia” mieszkańców Łodzi nie zostały poddane daleko idącej krytyce, która mogłaby je oczyścić zarówno z manier literackich epoki, jak i z częstego w niej dydaktyzmu. Trudno oprzeć się wrażeniu, że zarówno reymontowska wizja „ziemi obiecanej”, jak i „złe miasto” Z. Bartkiewicza, traktowane są jako „fotografie XIX-wiecznej rzeczywistości”.
\end{abstract}

Szkoda, że przed sformułowaniem tak kategorycznych uwag K.P. Woźniak nie sięgnął do moich publikacji poświęconych Łodzi, a opartych również o źródła prasowe, zobaczyłby bowiem wtedy, że bardzo daleko mi od traktowania ich w sposób bezkrytyczny. Chociażby w swojej książce o obrazie Łodzi w prasie warszawskiej piszę:

Duży wpływ na kształtowanie się obrazu miasta miała też jednak - jak sądzę - typowa dla prasy skłonność do eksponowania łatwych w odbiorze, intrygujących problemów i wyda-

${ }^{25}$ Zob.: K. Śmiechowski, W. Marzec, Pathogenesis of the Polish Public Sphere. The Intelligentsia and Popular Unrest during and after the 1905 Revolution, "Polish Sociological Review" 2016, nr 4 (196), s. 437-457; W. Marzec, Rebelia i reakcja. Rewolucja 1905 roku i plebejskie doświadczenie polityczne, Łódź-Kraków 2016. 
rzeń. [...] Łódź, z natury swej dotknięta w nieporównywalnie większym stopniu różnymi negatywnymi odcieniami nowoczesności, dostarczała sporo „gorących” tematów do „zgłębiania" redakcjom stołecznych tygodników.

Wszystkie te zastrzeżenia prowadziły do wykreowania stereotypu Łodzi jako miasta obcego, złego, zwyrodniałego ${ }^{26}$.

Nie wydaje mi się, by były to słowa kogoś bezkrytycznie podchodzącego do przekazów prasowych i literackich. Podobnie bezkrytycznym ich referowaniem nie jest rozdział mojego autorstwa. Warto nadmienić jednak, że również jednak i sama analiza dyskursu, podobnie jak dorobek znanych przecież Recenzentowi historyków prasy takich jak Zenon Kmiecik czy Jerzy Myśliński, nie jest streszczaniem treści zawartych na łamach prasy lecz rozwiniętą teoretycznie praktyką badawczą o wypracowanej metodologii ${ }^{27}$.

Problemem nie jest jednak to z jakiego rodzaju źródeł i metodologii korzysta się lecz to jak się z nich korzysta. W tym kontekście zarzut „zafascynowania” starymi gazetami jest o tyle chybiony, że nigdzie nie ukrywam w oparciu o jakie źródła zamierzam analizować temat roli robotników w życiu miasta, przeciwnie, decydując się na wybór źródeł opisowych świadomie zamierzam wyeksponować to, jak postrzegano ów problem. Wada źródeł opisowych, czyli ich narracyjność, staje się w tym kontekście ich zaletą, pozwala bowiem odpowiedzieć na pytanie dlaczego Łódź przełomu wieków nie była uważana za miasto robotników, mimo, że - co starałem się wyżej dowieść - społeczność ta stanowiła zdecydowaną większość mieszkańców miasta. Prowokując czytelników, w tym i Recenzenta do poszukiwania nowych pól badawczych oraz formułowania polemik, zdaję sobie sprawę ze wszystkich konsekwencji wynikających $\mathrm{z}$ takiego podejścia badawczego. Tyle tylko, że przy skromności źródeł narracyjnych mówiących o życiu przemysłowego miasta na przełomie wieków, prasa staje się nie tylko podstawowym, ale niekiedy wręcz jedynym sposobem uzyskiwania informacji.

Niniejsza odpowiedź na artykuł recenzyjny nie jest rzecz jasna miejscem, by rozprawiać się z anachronizmem rozumowania hierarchizującego źródła historyczne, warto jednak zaryzykować zastanowienie się skąd u Recenzenta, który w pewnym miejscu zarzuca mi wręcz „fascynację przekazem literackim” tak wyrazista niechęć do źródeł tego typu, a co za tym idzie metodologii przesuwających nacisk na źródła narracyjne. Obawia się więc K.P. Woźniak, jak sądzę, iż zauważalny w ostatnich latach zwrot $\mathrm{w}$ tym kierunku skutkować może dalszym odpływem badaczy od pracy nad zasobem archiwalnym oraz zatarciem różnic między historiografią a innymi naukami społecznymi. Problem istotnie pogłę-

${ }^{26}$ K. Śmiechowski, Z perspektywy stolicy. Łódź okiem warszawskich tygodników spoleczno-kulturalnych 1881-1905, Łódź 2012, s. 206-207.

${ }^{27}$ Szczególnie godny polecenia jest podręcznik metodologiczny PWN: Jakościowa analiza dyskursu w naukach społecznych, red. R. Wodak, M. Krzyżanowski, Warszawa 2011. 
bia się, m.in. na skutek braku edukacji młodzieży w zakresie języka rosyjskiego (może powinien być on, wraz z niemieckim, obowiązkowym przedmiotem dla studentów historii Polski? - K.Ś.), a także zmian kulturowych, których pokłosiem jest również zjawisko „Zwrotu językowego” we współczesnej humanistyce.

Tym, co czyni litanię zarzutów K.P. Woźniaka wobec naszej książki niesprawiedliwą jest jednak fakt, iż w żadnym jej miejscu nie nawołujemy do porzucenia tradycyjnych źródeł i metod badawczych historiografii na rzecz rozmaitych nowinek. Nie odcinamy się przecież od dorobku łódzkiej historiografii „tradycyjnej”, z której całymi garściami czerpiemy starając się - tam, gdzie jest to uzasadnione - odsiewać z niej odium ,złych czasów”. Nie chodzi zatem ani mnie, ani współautorom, o to, by nowe kierunki badawcze wyparły stare, lecz raczej o to, by - jak piszemy we Wstępie - książkę tę traktować jako „zaproszenie do powrotu i kontynuacji badań nad bardzo rozległym i wieloaspektowym zagadnieniem życia i działalności robotników”28. Co oczywiste, podkreślamy, że „praca ta stanowi jedynie wycinek możliwości badawczych w zakresie szeroko rozumianej problematyki robotniczej”'29.

Krzysztof P. Woźniak oczekuje zaś od naszych rozważań kompleksowości, której uzyskanie możliwe będzie dopiero wówczas, gdy badania nad łódzką społecznością robotniczą ulegną gwałtownej intensyfikacji. My zaś, głównie na skutek zmian w historiografii, które nastąpiły po 1989 r., jesteśmy niemalże na początki drogi. Pomimo oczywistego niezrozumienia przez Recenzenta naszej książki i stojących za nią intencji uznać wypada, iż bardzo dobrze, że po wielu latach nowa publikacja poruszająca problem robotników Łodzi wielkoprzemysłowej wreszcie powstała. Odrzucając, niekiedy dogmatycznie, nowe podejścia i metody badawcze we współczesnej humanistyce, w tym także w historiografii regionalnej, bynajmniej nie zwiększymy bowiem zastępów chętnych, którzy chcieliby poświęcić się - co chciałbym podkreślić - w bardzo potrzebnej i wartościowej, „klasycznej” pracy badawczej na tym trudnym polu, a co gorsza wystraszymy tych, którzy chcą się tym tematem zajmować na swój własny sposób, poszukując odpowiedzi na pytania ważne dla nich, a nie dla najzacniejszych nawet mistrzów...

Słowa kluczowe: artykuł polemiczny, robotnicy, Łódź, XIX wiek

Keywords: article polemic, workers, Łódź, XIX ${ }^{\text {th }}$ century

${ }^{28}$ Wstep..., s. 11.

${ }^{29}$ Tamże. 